\title{
Remote sensing and GIS application for monitoring drought vulnerability in Indonesia: a review
}

\author{
Khalifah Insan Nur Rahmi ${ }^{1}$, Muhammad Dimyati ${ }^{2}$ \\ ${ }^{1}$ Department of Geography, Faculty of Mathematics and Natural Sciences, Universitas Indonesia, Indonesia \\ ${ }^{1,2}$ Remote Sensing Application Centre, National Institute of Aeronautics and Space, Indonesia
}

\section{Article Info \\ Article history: \\ Received Jun 17, 2021 \\ Revised Sep 8, 2021 \\ Accepted Oct 31, 2021}

\section{Keywords:}

Agricultural drought

Drought mapping

Drought vulnerability

GIS

Hydrometeorological disaster

Land surface temperature

Remote sensing

\begin{abstract}
Agricultural drought is one of the hydrometeorological disasters that cause significant losses because it affects food stocks. In addition, agricultural droughts, impact the physical and socio-economic development of the community. Remote sensing technology is used to monitor agricultural droughts spatially and temporally for minimizing losses. This study reviewed the literature related to remote sensing and GIS for monitoring drought vulnerability in Indonesia. The study was conducted on an island-scale on Java Island, a provincial-scale in East Java and Bali, and a district-scale in Indramayu and Kebumen. The dominant method was the drought index, which involves variable land surface temperature (LST), vegetation index, land cover, wetness index, and rainfall. Each study has a strong point and a weak point. Low-resolution satellite imagery has been used to assess drought vulnerability. At the island-scale, it provides an overview of drought conditions, while at the provincial-scale, it focuses on paddy fields and has little detailed information. In-situ measurements at the district-scale detect meteorological drought accurately, but there were limitations in the mapping unit's detailed information. Drought mapping using GIS and remote sensing at the district-scale has detailed spatial information on climate and physiographic aspects, but it needs temporal data monitoring.
\end{abstract}

This is an open access article under the CC BY-SA license.

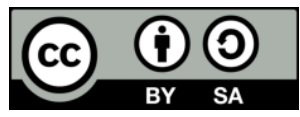

\section{Corresponding Author:}

Muhammad Dimyati

Department of Geography, Faculty of Mathematics and Natural Sciences

Universitas Indonesia

Jl. Margonda Raya, Pondok Cina, Kecamatan Beji, Kota Depok, Jawa Barat 16424, Indonesia

Email: m.dimyati@sci.ui.ac.id

\section{INTRODUCTION}

Drought is a natural disaster in the form of a lack of water for a certain period which causes a problem to activities, groups, and other environmental sectors [1]. In 2016, Hobbins et al. [2] explained that meteorological drought would decrease evapotranspiration and groundwater moisture in agricultural drought. The meteorological drought would also decrease river flow and surface storage in hydrological drought. Wilhite, 1985 and UN/ISDR, 2007 [3], [4] define that there are four types of droughts, i.e. (1) meteorological drought, (2) agricultural drought, (3) hydrological drought, and (4) socio-economic drought. The drought process begins with a decrease in rainfall intensity from normal conditions in a season called a meteorological drought [5]-[7]. Then there is a deficit of groundwater so that it is no longer able to meet water needs for plants, or it is known as agricultural drought [8], [9]. The final process, which is a reduction of surface water supply and groundwater in the long term and can potentially impact the social, economic, and environmental sectors, is known as hydrological drought [10]. 
Drought in Indonesia often occurs during the dry season but gets worse during El-Nino events such as in 1988, 1999, 2007, and 2015 [11]-[13]. Drought causes physical problems such as crop failure (puso) [14], [15] and triggering forest and land fires [16]. Java Island, as the highest population in Indonesia, has main foodstuff rice. The occurrence of puso on agricultural land will have severe consequences on the population. Various studies on agricultural drought in Indonesia have been conducted using both in-situ data and remote sensing data. In-situ data uses precipitation from meteorology stations [17]. In 2017, Adhyani [17] examine drought using standardized precipitation index (SPI) from precipitation station data in Java, Bali, and Nusa Tenggara. A combination of spatial and in-situ data to identify drought has been studied by Habibie et al. [18] in East Java. Drought assessment in Indonesia using remote sensing data such as Dirgahayu [19], which examines Indramayu Regency. As well as outside Java, such as in Batam by Lubis et al. [20] shows the importance of analyzing agricultural drought in Indonesia.

Remote sensing and GIS provide a spatial description of an area; therefore, analysis of agricultural drought is widely studied for monitoring large areas with this technology [21]. The use of the drought index has grown over time [22]-[24]. Starting with the SPI index based on rainfall [6], [25]-[28], palmer drought severity index (PSDI) [5] based on rainfall and soil moisture, standardize precipitation evapotranspiration index (SPEI) based on rainfall and evapotranspiration [29]-[31], temperature vegetation dryness index (TVDI) [32] and vegetation temperature condition index (VTCI) [33]-[35] based on vegetation and temperature. Then this index develops into drought index groups. The drought index groups based on vegetation include moisture stress index (MSI) [36], simple ratio water index (SRWI) [37], normalized difference water index (NDWI) [38], normalized difference drought index (NDDI) [39], land surface water index (LSWI) [40], vegetation condition index (VCI) [30], [41], [42], and drought severity index (DSI) [43]-[45]. Index groups based on soil physical conditions are perpendicular drought index (PDI) [46], [47]. Combination of vegetation and soil in the study of Wang et al. [47] and Ahmadalipour et al. [48]. Also, indices that combine both of them i.e. shortwave infrared water stress index (SIWSI) [49], normalized multiband drought index (NDMI) [50], and visible and shortwave drought index (VSDI) [51]. The combination between indices has been studied by Fang et al. [52] which combine NDVI and SPI using the copula method [53], [54] while Zuo et al. [55] combine rainfall and NDVI which is called combine deficit index (CDI). Until now more indices have been developed with machine learning and cloud computing technologies. In 2020, Liu et al. [56] build the IDI index using neural network machine learning while Han et al. [57] investigate the relationship between drought and precipitation, temperature, vegetation, and evapotranspiration using random forest. Meteorological drought forecast using machine learning had been performed by Rhee and Im [58]. Early use of cloud computing technologies combined Google Earth Engine (GEE) and GIS technology such as Sazib et al. [59] and Shen et al. [60] build comprehensive meteorology and agriculture drought models using deep learning. It assesses drought using global soil moisture data, land cover, and SPI. Meanwhile, GEE to compute several indices of drought indicators in Vietnam found that NDDI is good for agricultural land and vegetation health indeks (VHI) good for forestry [61]. In 2021, Venkatappa et al. [62] used GEE to know the impact of drought and flood on cropland and crop production in Southeast Asia.

Drought monitoring using remote sensing and GIS technology has been widely used in Indonesia but never reviewed technology used in different study scales. The review can be used to analyze the strength and weaknesses of the method that could be improved in the next study. The monitoring of drought in Indonesia from remote sensing data has been carried out based on the VHI index with MODIS and TRMM images on an island-scale by Roswintiarti et al.[63] and on provincial-scale by Amalo et al. [64]. Dirgahayu [19] also use MODIS and TRMM images at the regency-scale based on a combination of drought types. Prasetyo et al. [65] conducted drought monitoring using Landsat-8 images at province-scale in Central Java using vegetation index and machine learning. At the district-scale, they used Landsat-8 imagery with VHI index [66] and NDDI index [67]. The use of in-situ data on a district-scale has been performed by Pramudya et al. Geographic Information System (GIS) techniques are also used for combining drought type [19] and analyzing the spatial distribution [66]. All the studies mentioned in Indonesia focus on agricultural land especially the paddy field. Therefore, it is important to review drought vulnerability assessment, especially in paddy fields. This study aims to review several scientific studies about agricultural drought in Indonesia using remote sensing and GIS.

\section{RESEARCH METHOD}

The locations of reviewed studies consisted of three regional coverage scales in Indonesia, i.e. (1) island-scale with the case study of Java Island [63], (2) provincial-scale with the case study of East Java [68], and (3) district-scale with case studies of Indramayu [19], Tegal [68], and Subang and Karawang [66]. Figure 1 shows that Java Island located in $106^{\circ} 00^{\prime} \mathrm{E}-116^{\circ} 00^{\prime} \mathrm{E}$ and $6^{\circ} 00^{\prime} \mathrm{S}-8^{\circ} 30$ 'S, East Java province located in $111^{\circ} 00^{\prime} \mathrm{E}-114^{\circ} 30^{\prime} \mathrm{E}$ and $6^{\circ} 30^{\prime} \mathrm{S}-9^{\circ} 15^{\prime} \mathrm{S}$. At a district-scale, Indramayu located in $108^{\circ} 00^{\prime}-108^{\circ} 30^{\prime}$ and $6^{\circ} 15^{\prime \prime}-$ 
$6^{\circ} 40^{\prime \prime}$, Tegal located in $108^{\circ} 55^{\prime} \mathrm{E}-109^{\circ} 20^{\prime} \mathrm{E}$ and $6^{\circ} 50^{\prime}-7^{\circ} 10^{\prime} \mathrm{S}$, Subang and Karawang located in $107^{\circ} 00^{\prime}-108^{\circ} 00^{\prime}$ and $6^{\circ} 00^{\prime \prime}-6^{\circ} 50^{\prime \prime}$. The location selection represents each mapping scale and the study location that can be significantly affected by drought and uses different methods to be compared with one another.

Monitoring of drought vulnerability was conducted in Java Island from June to August 2009 when ENSO occurred. On the provincial-scale in East Java, monitoring is conducted during drought periods in the El Nino event 2015. In the Indramayu district, a drought monitor was conducted in the year 2008. In Tegal, the district study is analyzed based on the precipitation index which focuses on the El Nino event from 1985-2015. In Subang and Karawang districts, the study is conducted in the dry season of 2000, 2005, 2010, and 2015.

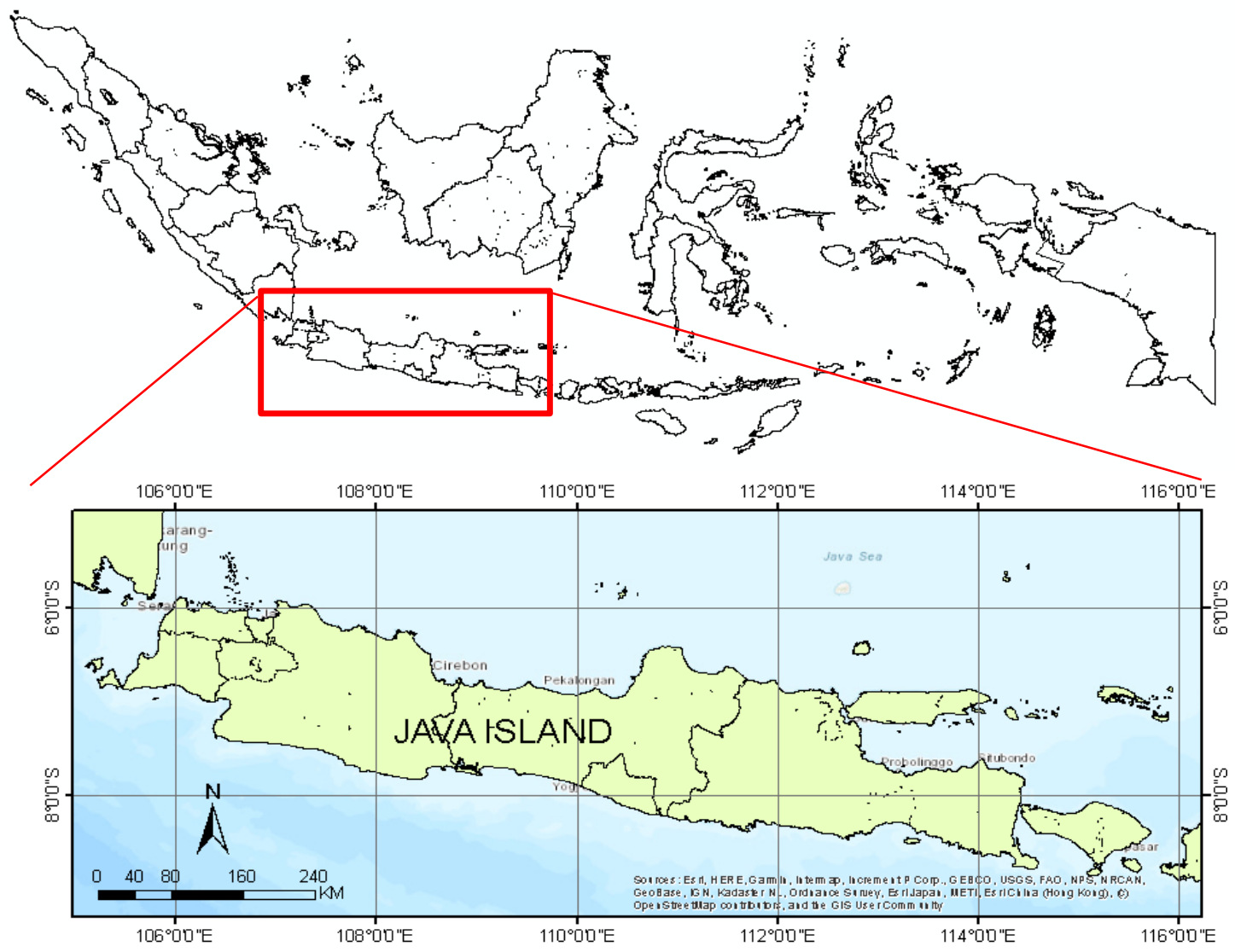

(a)

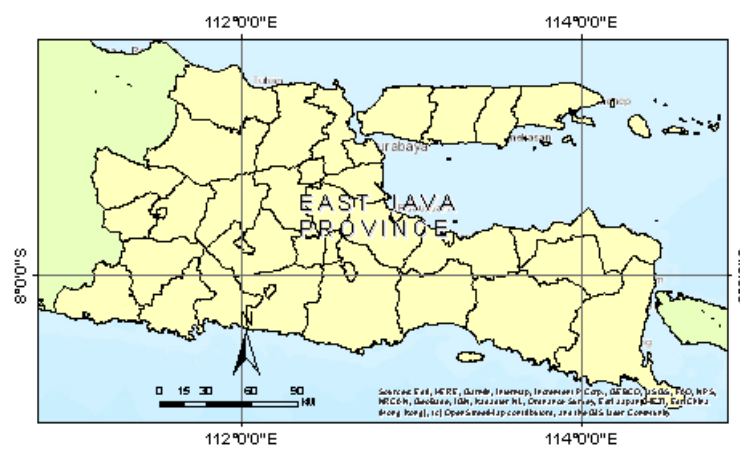

(b)

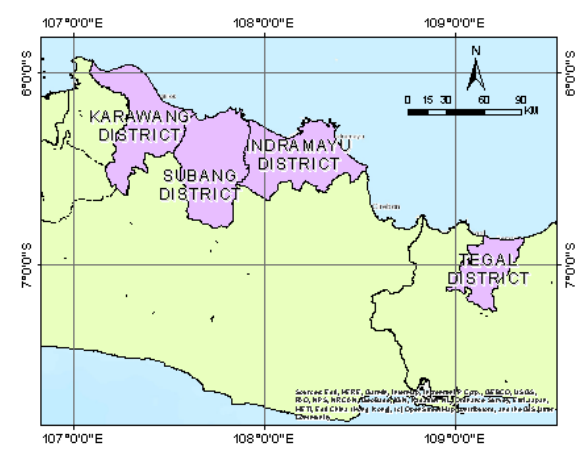

(c)

Figure 1. Study area in Indonesia; (a) island scale: Java Island, (b) province scale: East Java, (c) district scale: Indramayu, Tegal, Subang and Karawang

The data used was divided into three categories i.e., remote sensing data in raster format, shape files in vector format, and in-situ data. Remote sensing imagery that has been used is $1 \mathrm{x} 1 \mathrm{~km}$ MODIS lowresolution is extracted into land surface temperature (LST), enhanced vegetation index (EVI), and NDVI 
variables [19], [63], [64]. The TRMM precipitation image has a spatial resolution of $1 \mathrm{x} 1 \mathrm{~km}$ [19], [63]. Medium resolution images of Landsat-8, i.e., OLI with a pixel size of $30 \times 30 \mathrm{~m}$ and TIRS with a pixel size of $100 \times 100 \mathrm{~m}$ to extract NDVI and LST [66]. Vector data represent paddy field areas and administrative boundaries. Also, there is in-situ data in the form of rainfall data from Tegal city station located in $6^{\circ} 87^{\prime} \mathrm{S}$ and $109^{\circ} 12^{\prime}$ E, $54.0 \mathrm{~m}$ above sea level.

Table 1. Method comparison of drought monitoring research in Indonesia

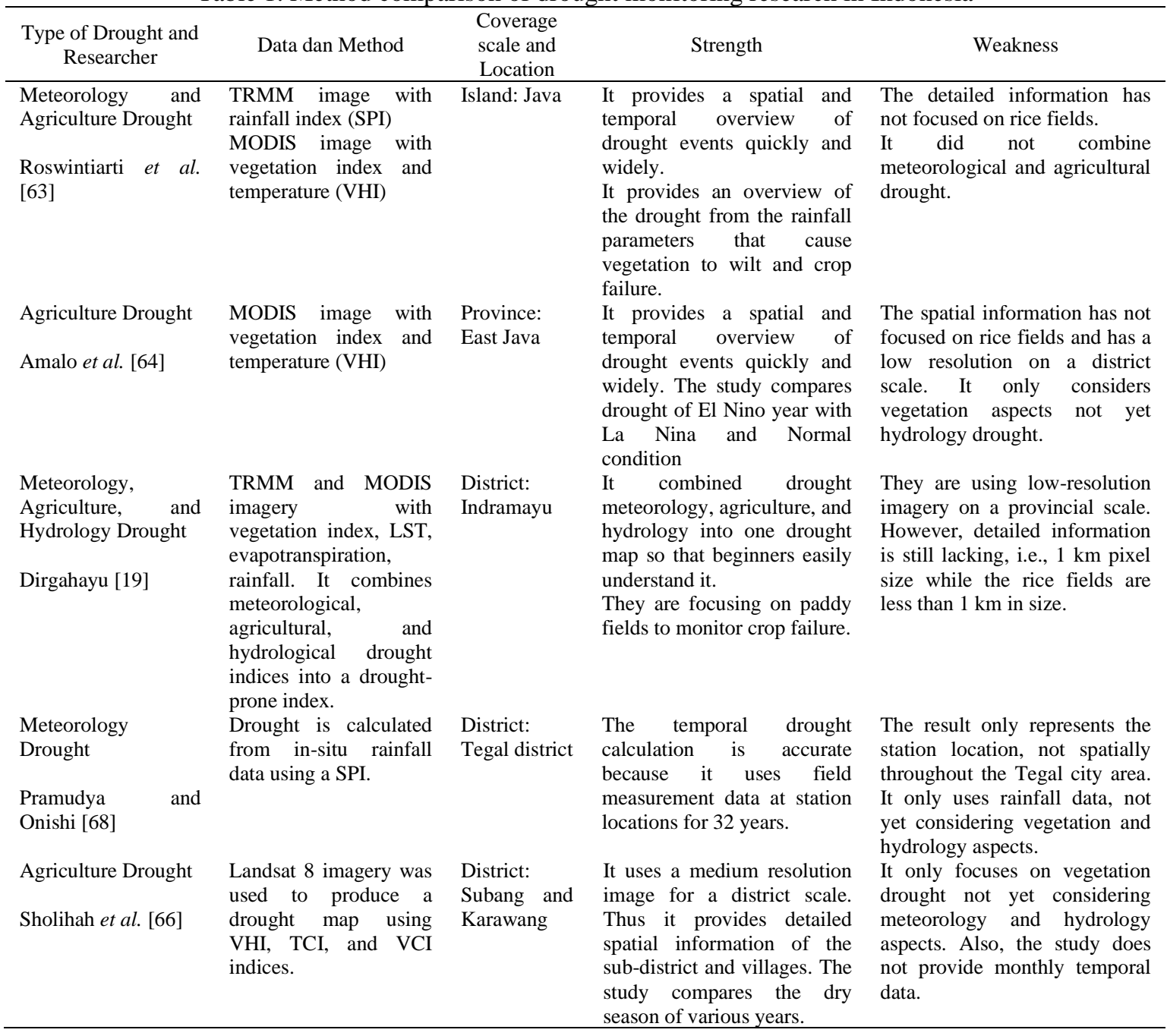

SPI is a method to calculate the meteorological drought of an area. In this study, it is used to identify meteorology dought of island scale by Roswintiarti et al.[63] and district scale by Dirgahayu [19] and Pramudya et al. [68]. The SPI index is extracted from long-term normalized and average monthly rainfall values. The following is SPI formula [6]:

$$
S P I=\frac{X_{i j}-X_{i m}}{\sigma}
$$

where $\mathrm{Xij}$ is actual rainfall, Xim is the long-term mean rainfall, and $\sigma$ is its standard deviation.

VHI is a remote sensing index based on the vegetation and the land surface temperature. This index reflects vegetation stress due to adverse climatic factors. VHI is calculated to identify the agricultural drought of an area. In this study, this index is used by Roswintiarti et al.[63] to identify drought on an island scale, Amalo et al. [64] on the provincial scale and Sholihah et al. [66] on the district scale. The VHI formula is explained as [41]:

$$
V H I=0.5(V C I+T C I)
$$


where VCI is vegetation condition index, and TCI is temperature condition index. VCI and TCI formula is described as:

$$
\begin{aligned}
& V C I=100 \times \frac{V I-V I_{\min }}{V I_{\max }-V I_{\min }} \\
& T C I=100 \times \frac{L S T_{\max }-L S T}{L S T_{\max }-L S T_{\min }}
\end{aligned}
$$

Where VI is vegetation index (EVI or NDVI) and LST is land surface temperature.

In 2012, Dirgahayu [19] developed a method for monitoring district-scale drought vulnerability. They were combining meteorological, agricultural, and hydrological drought indices. The meteorological drought index is based on rainfall and evapotranspiration data. The agricultural drought index is based on the value of the enhanced vegetation index (EVI). The hydrological drought index is based on soil moisture index extracted from MODIS band 6,2,1.

\section{RESULTS AND DISCUSSION}

Monitoring of drought vulnerability in Java while ENSO 2009 happened based on research Roswintiarti et al. [63]. It shows mild drought conditions throughout Java due to a lack of rainfall since June leading to meteorological drought. The method is an SPI index with an index value of $1.0 \leq \mathrm{SPI}<0$ in Figure 2. As a result, the meteorological drought continued into an agricultural drought. It is shown by the VCI and TCI index values $t$, which is less than 36 . Both showed vegetation stress where VCI from the humidity aspect developed in East Java in Figure 3 while TCI from the temperature developed in West Java in Figure 4.

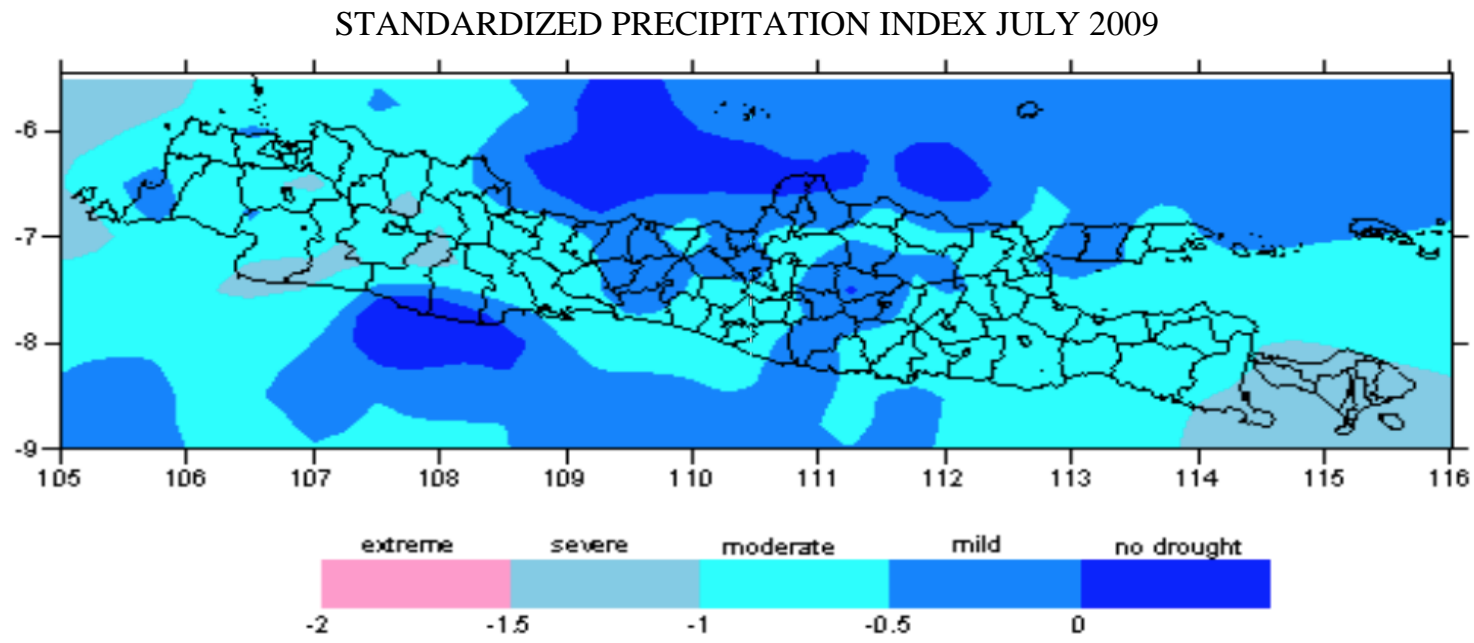

Figure 2. SPI Map of Java Island for July 2009 [63]

VEGETATION CONDITION INDEX JULY 2009

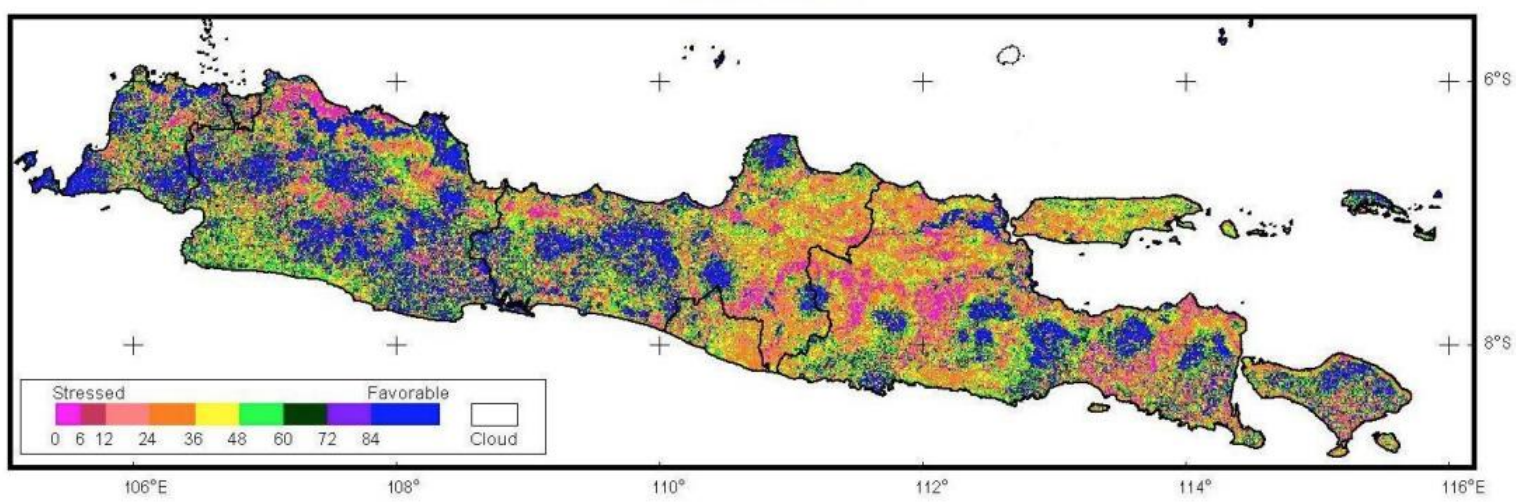

Figure 3. VCI Map of Java Island for July 2009 [63] 
The study of drought on Java Island provides an overview of the potential hazard of drought based on rainfall and vegetation conditions. Meteorological drought due to rainfall deficit in Java has occurred since June and extended to August 2009. From June to August 2009, there was also an agricultural drought in the form of vegetation stress. A map of agricultural drought or vegetation stress can be seen in Figure 5 . Drought and crop failure will result from the lowest vegetation stress in the paddy fields. Therefore, a severe drought appears to have occurred in several areas across the provinces of Java Island. This study provides an overview of the agricultural drought process that occurs due to a continuous deficit of rainfall, which is shown for three months. It has resulted in a severe agricultural drought.

\section{TEMPERATURE CONDITION INDEX JULY 2009}

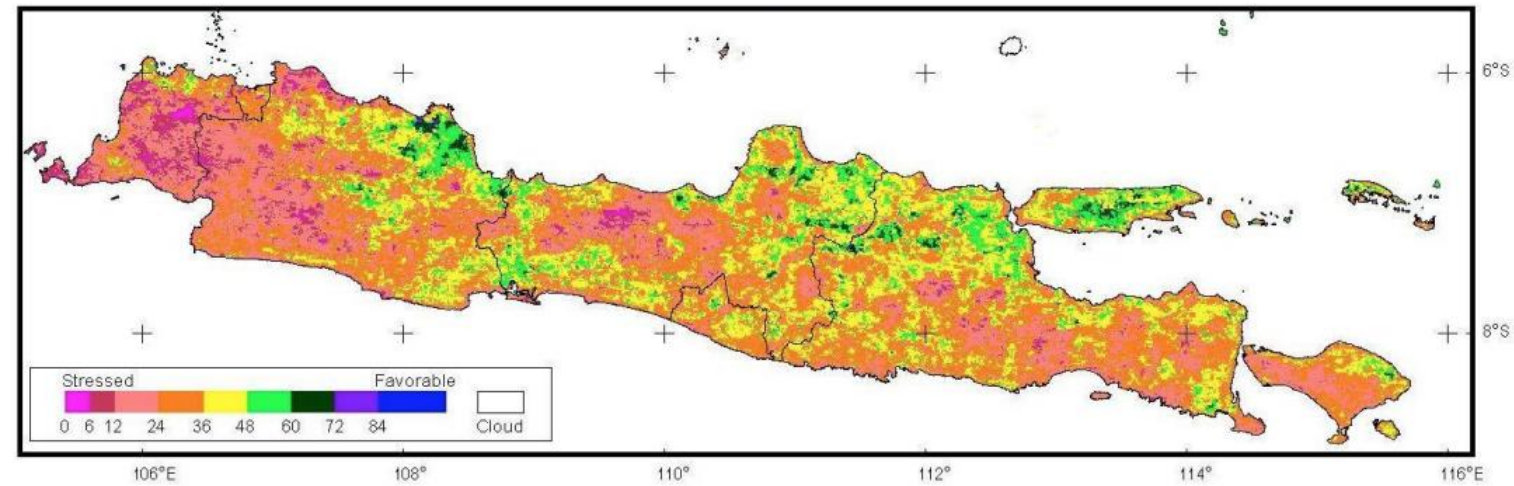

Figure 4. TCI Map of Java Island for July 2009 [63]

VEGETATION HEALTH INDEX JULY 2009

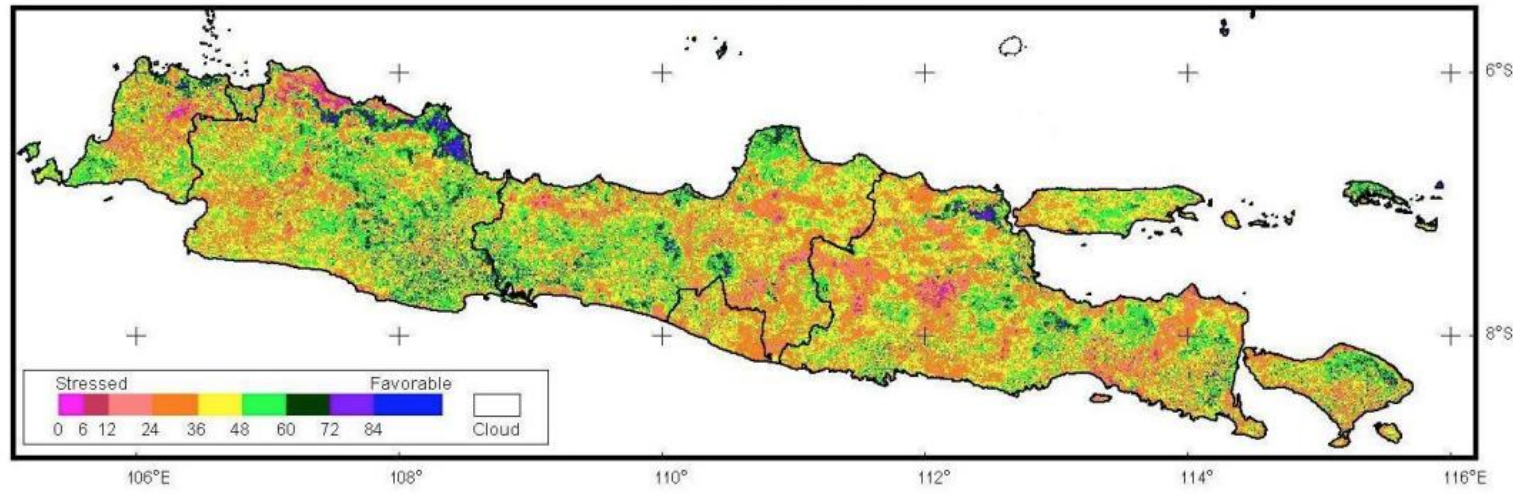

Figure 5. VHI Map of Java Island for July 2009 [63]

Drought vulnerability at the provincial scale has been studied by Amalo et al. [64] in East Java as the national agricultural production center. This study showed agricultural drought during EL-Nino in 2015 usually started in June, maximum in October, and ended in November. In Normal condition 2013, drought happens 3 months long, with area extent $115,443 \mathrm{~km}^{2}$ and severity of mild-extreme drought (VHI 0-40). ElNino 2015 condition gives impact to the long drought duration and the wider area extent than normal condition. Drought duration during EL-Nino happens 5 months with an areal extent of 197,343 $\mathrm{km}^{2}$. This study, also found that the most affected area by drought is in September-December, followed by MayAugust, and January-April. This agriculture drought correlated with rice production.

Amalo et al. [64] focus on monitoring agriculture drought monthly and compare between El-Nino, Normal, and La-Nina condition. Form the monthly information could be identified month of drought and could be compared one month condition to another month. The method in this study is similar to Roswintiarti et al which use MODIS to extract the VHI index. VHI index as the result of agricultural drought is shown in Figure 6. This study gives information on vegetation drought in $1 \mathrm{~km}$ resolution at the provincial-scale. This information represents the condition of the province in a wide area. However, it still needs improvement in considering another aspect such as rainfall that refers to meteorology drought or soil moisture that refers to hydrology drought. 


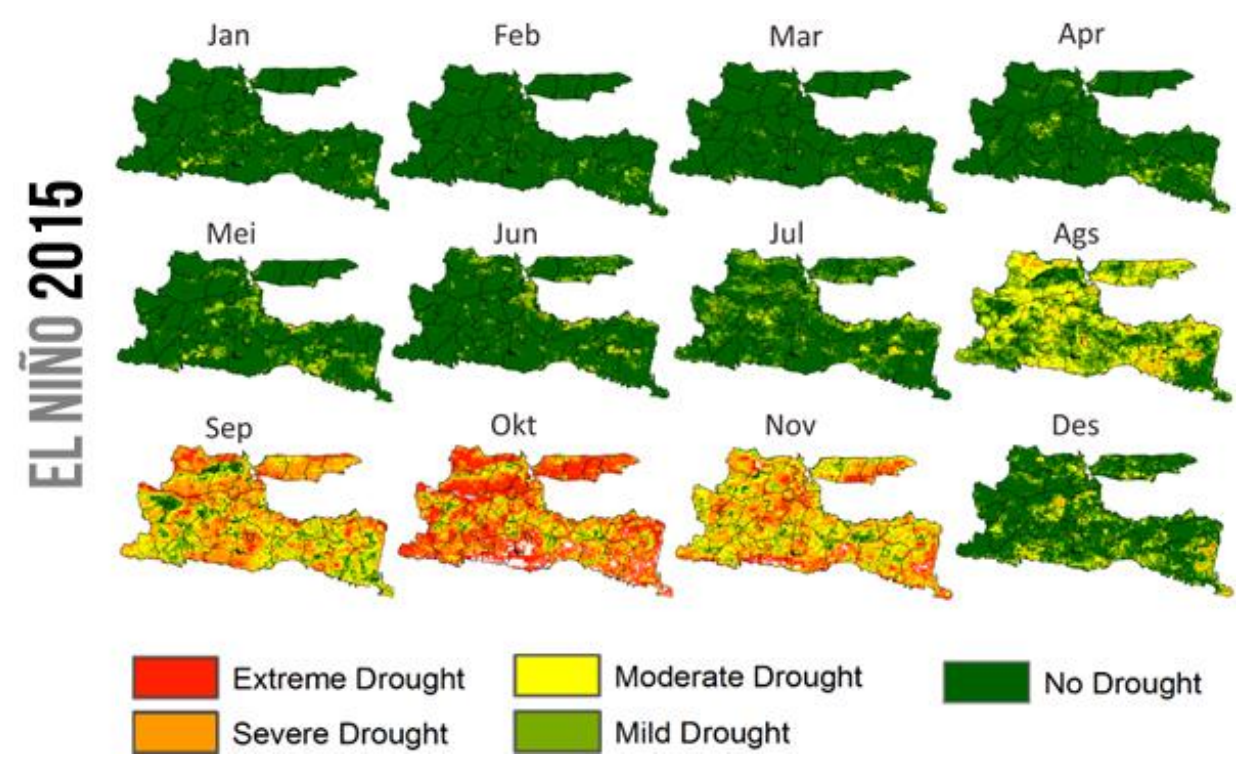

Figure 6. Monthly monitoring of agricultural drought 2015 in East Java Province [64]

In 2012, Dirgahyu [19] study about identifying drought vulnerability on a regional scale i.e. Indramayu district. This study builds the Indeks Rawan Kekeringan (IRK) algorithm which combines meteorology, vegetation, and hydrology droughts using MODIS and TRRM images and focuses on paddy fields. Model of IRK has been used in drought monitoring of LAPAN (https://sipandora.lapan.go.id/app/sipanda/sumber-daya-wilayah-darat/map/4321). Figure 7 shows the information on the drought map in the paddy field in August 2021.

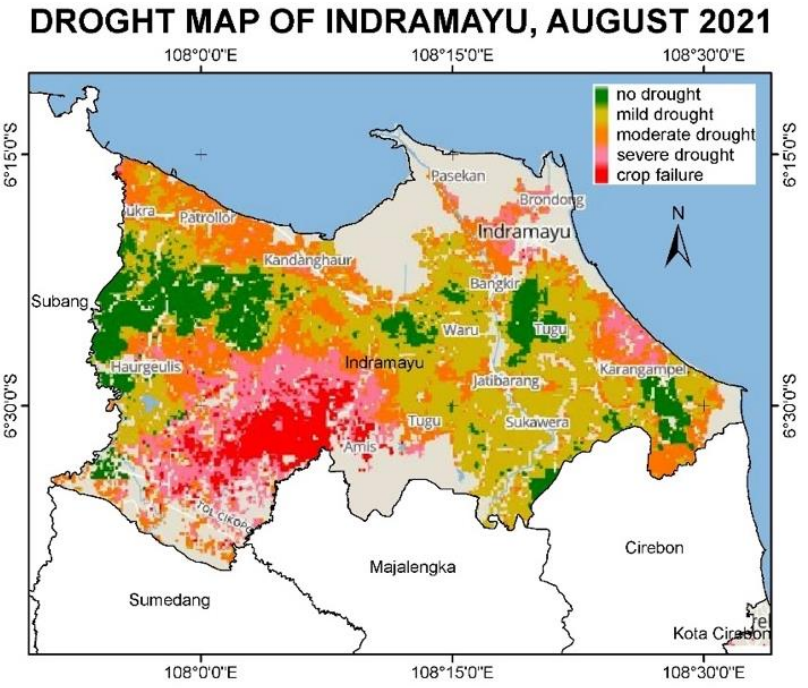

Figure 7. Drought map of paddy field in August 2021 in Indramayu District [19]

The study of Dirgahayu provides a complex alternative method of drought identification by paying attention to all types of drought by using the green level of vegetation (TKV), especially in paddy fields. TKV represents the condition of vegetation health, which is influenced by the amount of water. Low water in a long period will affect soil moisture which is called hydrology drought in this study. TKV and low rainfall cause a shortage of water supply, causing severe drought in Indramayu in Mei-August 2008. This study is more focused and detailed to maintain food availability and rice productivity. It gives a good temporal analysis of drought every 8 days using MODIS. However, it is a lack of spatial resolution which is a lack of information at the sub-district level. Also, this research still needs development in the accuracy check of the identification results. 
Another study at the district level was conducted by Pramudya and Onishi in 2018 using in-situ rainfall data [68]. The study calculates SPI for 30 years from 1982-2015. It shows that meteorology drought occurred in year 1982-2015 with index value respectively, for SPI 1 are (-3.11) in 1985 and (-2.51) in 2015, for SPI 3 are (-2.29) in 1997 and $(-1.82)$ in 2015, for SPI 6 are $(-2.40)$ in 1997 and $(-1.84)$ in 2015, for SPI 9 are $(-1.12)$ in 2015 , and for SPI 12 are $(-1.19)$ in 2015. Figure 8 reflects 32 years of SPI values in Tegal city. This study is accurate in the station location since it uses a direct measurement meteorological data station. However, this study only provides one station data location which does not represent another area of Tegal. Also, this study calculates drought from rainfall without considering vegetation and soil condition.

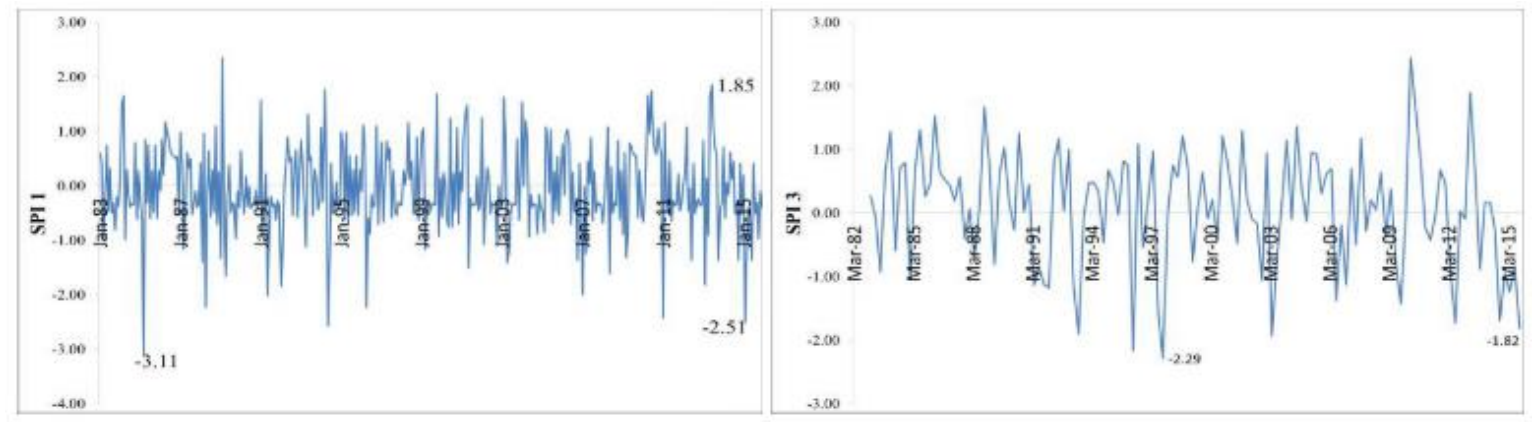

(a)

(b)

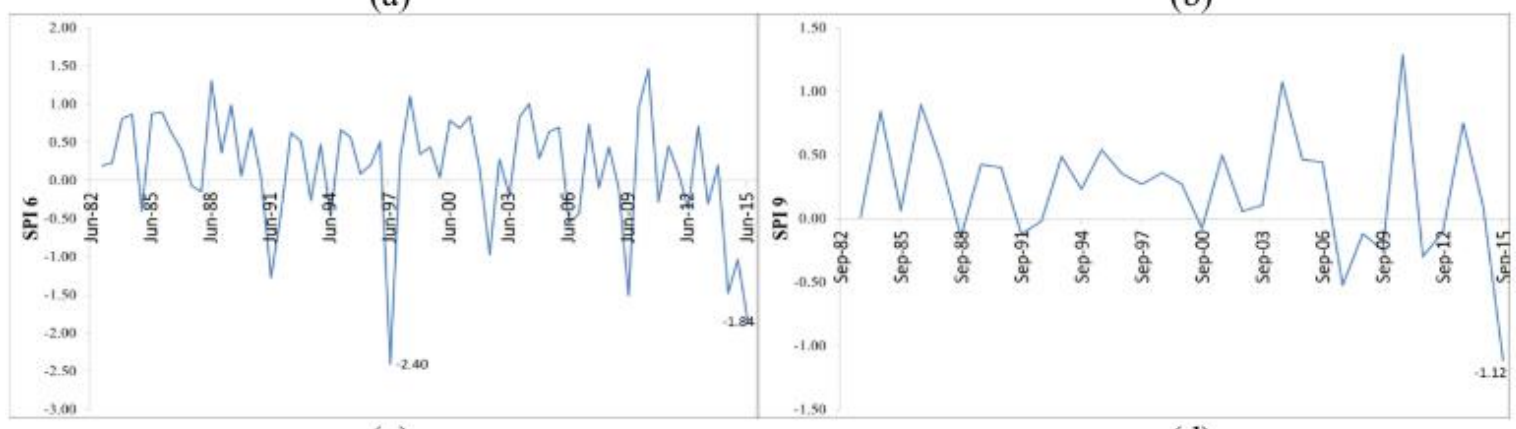

(c)

(d)

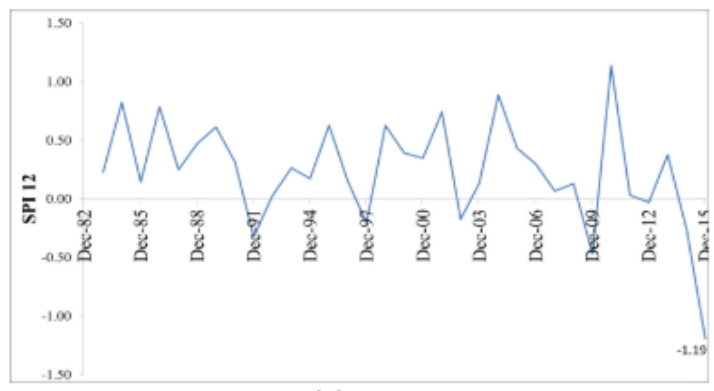

(e)

Figure 8. SPI values for Tegal city meteorological station with (a) 1-month time scale; (b) 3 month time scale; (c) 6-month time scale; (d) 9-month time scale; (e) 12-month time scale [68]

In 2016, Sholihah et al [66] conducted a study on drought in Subang and Karawang Districts in El Nino year 2015. The identified drought is vegetation drought from the VHI index which represents vegetation stress. Different from Roswintiarti et al. and Amalo et al., this study uses a Landsat-8 image that has a $30 \mathrm{~m}$ x $30 \mathrm{~m}$ pixel size. The result of this study has more detailed information than the study using MODIS at the district level. This study is suitable to interpret paddy fields with a small area. The result shows that drought intensified since 2000 and increased until 2015 significantly. Figure 9 represents VHI in 2000, 2005, 2010, and 2015 in Subang and Karawang Districts. Drought area and severity are increasing from 2000 to 2015 . The VHI decreased $50 \%$ and the increase of severity due to the rising of LST from $27^{\circ}$ to $40^{\circ} \mathrm{C}$. Using Landsat- 8 at the district level is the best choice. However, this study still needs improvement by enriching drought type with meteorology and hydrology drought, checking the accuracy of the model, and monitoring drought monthly. 


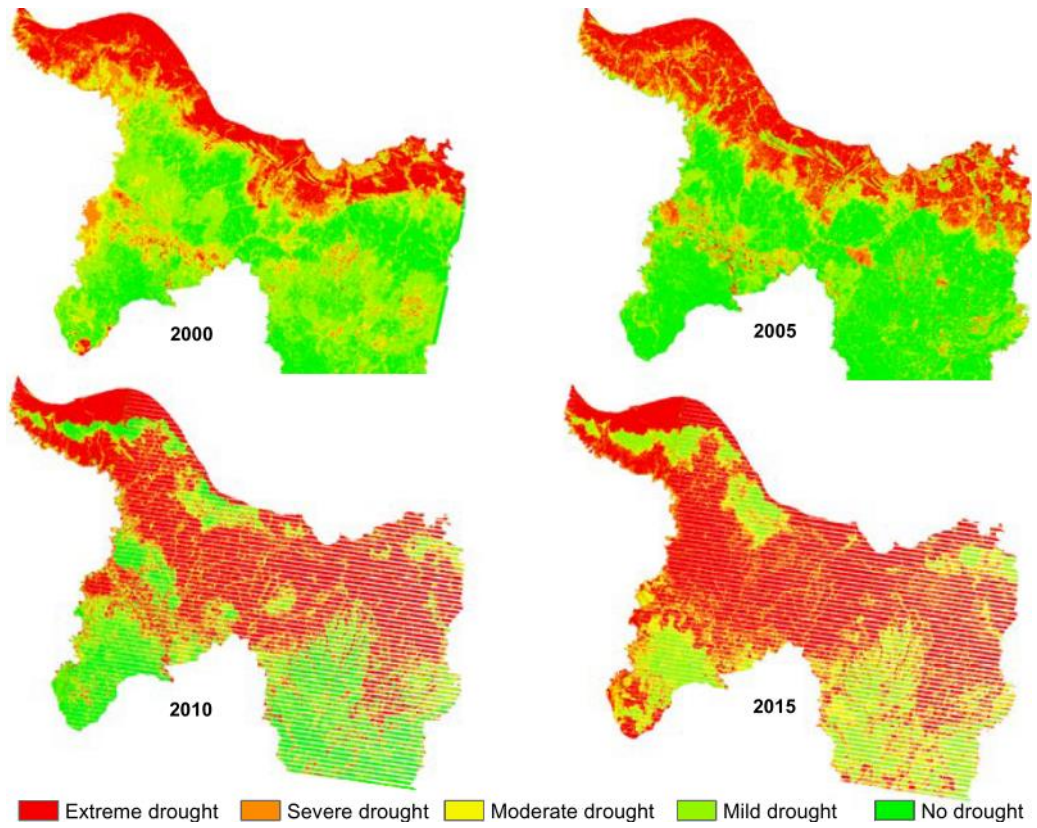

Figure 9. Drought map of Subang and Karawang [66]

\section{CONCLUSION}

Low-resolution remote sensing imagery is used in studies of drought vulnerability at the island and provincial-scales. It provides an overview of drought conditions at the island-scale, while it focuses on paddy fields at the provincial-scale. The drought occurs in June-September, but further research is needed for accuracy testing.

In-situ measurements at the district-scale are capable of detecting a meteorological drought accurately. However, it has limitations in terms of both spatial data distribution and detailed information. Medium-resolution remote sensing imagery and GIS data processing for drought vulnerability mapping at the district-scale shows detailed information. The combination method of meteorology, agriculture, and hydrology drought in terms of monthly drought monitoring are necessary to represent the rainfall, vegetation, and soil condition during drought episodes.

\section{ACKNOWLEDGEMENTS}

The authors would like to thank the LPDP (Education Fund Management Agency), Ministry of Finance of Indonesia, who supported the scholarships, and the Ministry of Education, Culture, Research and Technology for supporting research through the National Research Priority program. We also express our gratitude to LAPAN (National Institute of Aeronautics and Space) and the Universitas Indonesia for supporting and facilitating this research.

\section{REFERENCES}

[1] A. K. Mishra and V. P. Singh, "A review of drought concepts," Journal of Hydrology, vol. 391, no. 1, pp. 202-216, 2010, doi: 10.1016/j.jhydrol.2010.07.012.

[2] M. T. Hobbins et al., "The evaporative demand drought index. Part I: Linking drought evolution to variations in evaporative demand," Journal of Hydrometeorology, vol. 17, no. 6, pp. 1745-1761, 2016, doi: 10.1175/JHM-D-15-0121.1.

[3] D. A. Wilhite and M. H. Glantz, "Understanding: the Drought Phenomenon: The Role of Definitions," Water International, vol. 10, no. 3, pp. 111-120, Jan. 1985, doi: 10.1080/02508068508686328.

[4] UN/ISDR and U. N. secretariat of the I. S. for D. R. (UNISDR), "Drought Risk Reduction, Framework and Practices," no. May, p. 2007, [Online]. Available: https://www.unisdr.org/files/11541_DroughtRiskReduction2009library.pdf

[5] W. C. Palmer, "Meteorological Drought," U.S. Weather Bureau, Res. Pap. No. 45. p. 58, 1965. [Online]. Available: https://www.ncdc.noaa.gov/temp-and-precip/drought/docs/palmer.pdf

[6] T. B. McKee, N. J. Doesken and J. Kleist, "The relationship of drought frequency and duration to time scales," in Proceedings of the 8th Conference on Applied Climatology, 1993, vol. 17, no. 22, pp. 179-183.

[7] A. K. Mishra and V. P. Singh, "Drought modeling - A review," Journal of Hydrology, vol. 403, no. 1, pp. 157-175, 2011, doi: 10.1016/j.jhydrol.2011.03.049. 
[8] B. Narasimhan and R. Srinivasan, "Development and evaluation of Soil Moisture Deficit Index (SMDI) and Evapotranspiration Deficit Index (ETDI) for agricultural drought monitoring," Agricultural and Forest Meteorology, vol. 133, no. 1-4, pp. 69-88, 2005, doi: 10.1016/j.agrformet.2005.07.012.

[9] R. Wu, Y. Liu and X. Xing, "Evaluation of evapotranspiration deficit index for agricultural drought monitoring in North China," Journal of Hydrology, vol. 596, p. 126057, 2021, doi: https://doi.org/10.1016/j.jhydrol.2021.126057.

[10] Z. W. Kundzewicz et al., "Freshwater resources and their management," Climate Change 2007: Impacts, Adaptation and Vulnerability. Contribution ofWorking Group II to the Fourth Assessment Report of the Intergovernmental Panel on Climate Change, no. December 2016, pp. 173-210, 2007.

[11] X. Pan, M. Chin, C. M. Ichoku and R. D. Field, "Connecting Indonesian fires and drought with the type of El Niño and phase of the Indian Ocean dipole during 1979-2016," Journal of Geophysical Research: Atmospheres, vol. 123, no. 15, pp. 7974-7988, 2018, doi: 10.1029/2018JD028402.

[12] E. Surmaini and A. Faqih, "Extreme Climate Events and their Impacts on Food Crop in Indonesia," Water, pp. 1-4, 2016, [Online]. Available: http://repository.pertanian.go.id/handle/123456789/2245

[13] A. M. Setiawan, W. Lee and J. Rhee, "Spatio-temporal characteristics of Indonesian drought related to El Niño events and its predictability using the multi-model ensemble," International Journal of Climatology, vol. 37, no. 13, pp. 4700-4719, 2017, doi: 10.1002/joc.5117.

[14] R. Boer and A. Subbiah, "Agricultural Drought in Indonesia," 2005. doi: 10.1093/oso/9780195162349.003.0037.

[15] E. Surmaini, T. W. Hadi, K. Subagyono and N. T. Puspito, "Early detection of drought impact on rice paddies in Indonesia by means of Niño 3.4 index," Theoretical and Applied Climatology, vol. 121, no. 3-4, pp. 669-684, 2015, doi: 10.1007/s00704-014-1258-0.

[16] J. S. Littell, D. L. Peterson, K. L. Riley, Y. Liu and C. H. Luce, "A review of the relationships between drought and forest fire in the United States," Global change biology, vol. 22, no. 7, pp. 2353-2369, 2016, doi: $10.1111 / \mathrm{gcb} .13275$.

[17] N. L. Adhyani, T. June and A. Sopaheluwakan, "Exposure to Drought: Duration, Severity and Intensity (Java, Bali and Nusa Tenggara)," IOP Conference Series: Earth and Environmental Science, vol. 58, 2017, doi: 10.1088/1755-1315/5.

[18] M. I. Habibie, R. Noguchi, S. Matsushita and T. Ahamed, "Development of micro-level classifiers from land suitability analysis for drought-prone areas in Indonesia," Remote Sensing Applications: Society and Environment, vol. 20, no. October, p. 100421, 2020, doi: 10.1016/j.rsase.2020.100421.

[19] D. D. Dirgahayu, "Spatial Modelling of Rice Production Vulnerability Using Remote Sensing and GIS Technology (Case Studies in Indramayu Regency, West Java)," 2012, [Online]. Available: http://repository.ipb.ac.id/handle/123456789/61108

[20] M. Z. Lubis, H. M. Taki, W. Anurogo, D. S. Pamungkas, P. Wicaksono and T. Aprilliyanti, "Mapping the Distribution of Potential Land Drought in Batam Island Using the Integration of Remote Sensing and Geographic Information Systems (GIS)," IOP Conference Series: Earth and Environmental Science, vol. 98, no. 1, 2017, doi: 10.1088/1755-1315/98/1/012012.

[21] W. Jiao, L. Wang and M. F. McCabe, "Multi-sensor remote sensing for drought characterization: current status, opportunities and a roadmap for the future," Remote Sensing of Environment, vol. 256, no. January, p. 112313, 2021, doi: 10.1016/j.rse.2021.112313.

[22] K. Hazaymeh and Q. K. Hassan, "Remote sensing of agricultural drought monitoring: A state of art review," AIMS Environmental Science, vol. 3, no. 4, pp. 604-630, 2016, doi: 10.3934/environsci.2016.4.604.

[23] A. Aghakouchak et al., "Remote sensing of drought: Progress, challenges and opportunities," Reviews of Geophysics, vol. 53, pp. 1-29, 2015, doi: 10.1002/2014RG000456.Received.

[24] H. West, N. Quinn and M. Horswell, "Remote sensing for drought monitoring \& impact assessment: Progress, past challenges and future opportunities," Remote Sensing of Environment, vol. 232, no. July, p. 111291, 2019, doi: 10.1016/j.rse.2019.111291.

[25] T. Javed, N. Yao, X. Chen, S. Suon and Y. Li, "Drought evolution indicated by meteorological and remote-sensing drought indices under different land cover types in China," Environmental Science and Pollution Research, vol. 27, no. 4, pp. 4258-4274, 2020, doi: 10.1007/s11356-019-06629-2.

[26] T. Javed et al., "Performance and relationship of four different agricultural drought indices for drought monitoring in China's mainland using remote sensing data," Science of The Total Environment, vol. 759, p. 143530, 2021, doi: https://doi.org/10.1016/j.scitotenv.2020.143530.

[27] L. Xia, F. Zhao, K. Mao, Z. Yuan, Z. Zuo and T. Xu, "SPI-based analyses of drought changes over the past 60 years in China'S major crop-growing areas," Remote Sensing, vol. 10, no. 2, pp. 1-15, 2018, doi: 10.3390/rs10020171.

[28] E. Gidey, O. Dikinya, R. Sebego, E. Segosebe and A. Zenebe, "Modeling the Spatio-Temporal Meteorological Drought Characteristics Using the Standardized Precipitation Index (SPI) in Raya and Its Environs, Northern Ethiopia," Earth Systems and Environment, vol. 2, no. 2, pp. 281-292, 2018, doi: 10.1007/s41748-018-0057-7.

[29] V. Yevjevich, "An objective approach to definitions and investigations of continental hydrologic droughts," Journal of Hydrology, vol. 7, no. 3, p. 353, 1969, doi: 10.1016/0022-1694(69)90110-3.

[30] A. F. S. Ribeiro, A. Russo, C. M. Gouveia and P. Páscoa, "Modelling drought-related yield losses in Iberia using remote sensing and multiscalar indices," Theoretical and Applied Climatology, vol. 136, no. 1-2, pp. 203-220, 2019, doi: 10.1007/s00704-018-2478-5.

[31] V. Potopová, M. Trnka, P. Hamouz, J. Soukup and T. Castraveț, "Statistical modelling of drought-related yield losses using soil moisture-vegetation remote sensing and multiscalar indices in the south-eastern Europe," Agricultural Water Management, vol. 236, p. 106168, 2020, doi: 10.1016/j.agwat.2020.106168. 
[32] I. Sandholt, K. Rasmussen and J. Andersen, "A simple interpretation of the surface temperature/vegetation index space for assessment of surface moisture status," Remote Sensing of Environment, vol. 79, no. 2, pp. 213-224, 2002, doi: https://doi.org/10.1016/S0034-4257(01)00274-7.

[33] X. Hu et al., "Agricultural drought monitoring using European Space Agency Sentinel 3A land surface temperature and normalized difference vegetation index imageries," Agricultural and Forest Meteorology, vol. 279, p. 107707, 2019, doi: 10.1016/j.agrformet.2019.107707.

[34] X. Zhou, P. Wang, K. Tansey, S. Zhang, H. Li and L. Wang, "Developing a fused vegetation temperature condition index for drought monitoring at field scales using Sentinel-2 and MODIS imagery," Computers and Electronics in Agriculture, vol. 168, p. 105144, 2020, doi: 10.1016/j.compag.2019.105144.

[35] N. R. Patel, A. Mukund and B. R. Parida, "Satellite-derived vegetation temperature condition index to infer root zone soil moisture in semi-arid province of Rajasthan, India," Geocarto International, pp. 1-17, Dec. 2019, doi: 10.1080/10106049.2019.1704074.

[36] N. R. Dalezios, A. Blanta and N. V Spyropoulos, "Assessment of remotely sensed drought features in vulnerable agriculture," Natural Hazards and Earth System Sciences, vol. 12, no. 10, pp. 3139-3150, 2012, doi: 10.5194/nhess-12-3139-2012.

[37] P. J. Zarco-Tejada, C. A. Rueda and S. L. Ustin, "Water content estimation in vegetation with MODIS reflectance data and model inversion methods," Remote Sensing of Environment, vol. 85, no. 1, pp. 109-124, 2003, doi: 10.1016/S0034-4257(02)00197-9.

[38] B. Gao, "NDWI-A normalized difference water index for remote sensing of vegetation liquid water from space," Remote Sensing of Environment, vol. 58, no. 3, pp. 257-266, 1996, doi: 10.1016/S0034-4257(96)00067-3.

[39] L. Cheng-lin and W. Jian-jun, "Crop Drought Monitoring using MODIS NDDI over Mid-Territory of China," in IGARSS 2008 - 2008 IEEE International Geoscience and Remote Sensing Symposium, 2008, vol. 3, pp. III-883-III886. doi: 10.1109/IGARSS.2008.4779491.

[40] X. Xiao et al., "Satellite-based modeling of gross primary production in an evergreen needleleaf forest," Remote Sensing of Environment, vol. 89, no. 4, pp. 519-534, 2004, doi: https://doi.org/10.1016/j.rse.2003.11.008.

[41] F. Kogan, "World droughts in the new millennium from avhrr-based vegetation health indices," Eos, vol. 83, no. 48, pp. 3-7, 2002, doi: 10.1029/2002EO000382.

[42] H. Heydari, M. Valadan Zoej, Y. Maghsoudi and S. Dehnavi, "An investigation of drought prediction using various remote-sensing vegetation indices for different time spans," International Journal of Remote Sensing, vol. 39, no. 6, pp. 1871-1889, Mar. 2018, doi: 10.1080/01431161.2017.1416696.

[43] Q. Mu, M. Zhao, J. S. Kimball, N. G. McDowell and S. W. Running, "A remotely sensed global terrestrial drought severity index," Bulletin of the American Meteorological Society, vol. 94, no. 1, pp. 83-98, 2013, doi: 10.1175/BAMS-D-11-00213.1

[44] M. J. Um, Y. Kim and D. Park, "Evaluation and modification of the Drought Severity Index (DSI) in East Asia," Remote Sensing of Environment, vol. 209, no. February, pp. 66-76, 2018, doi: 10.1016/j.rse.2018.02.044.

[45] J. Huang et al., "Comparison of three remotely sensed drought indices for assessing the impact of drought on winter wheat yield," International Journal of Digital Earth, vol. 13, no. 4, pp. 504-526, Apr. 2020, doi: 10.1080/17538947.2018.1542040.

[46] A. Ghulam, Z.-L. Li, Q. Qin, H. Yimit and J. Wang, "Estimating crop water stress with ETM+ NIR and SWIR data," Agricultural and Forest Meteorology, vol. 148, no. 11, pp. 1679-1695, 2008, doi: 10.1016/j.agrformet.2008.05.020.

[47] H. Wang, N. He, R. Zhao and X. Ma, "Soil water content monitoring using joint application of PDI and TVDI drought indices," Remote Sensing Letters, vol. 11, no. 5, pp. 455-464, May 2020, doi: 10.1080/2150704X.2020.1730469.

[48] Ali Ahmadalipour, H. Moradkhan, M. Zarekarizi and H. Yan, "Remote Sensing of Drought: Vegetation, Soil Moisture and Data Assimilation," in Remote Sensing of Hydrological Extremes, Springer, Cham, 2017, pp. 121149. doi: 10.1007/978-3-319-43744-6_7.

[49] R. Fensholt and I. Sandholt, "Derivation of a shortwave infrared water stress index from MODIS near- and shortwave infrared data in a semiarid environment," Remote Sensing of Environment, vol. 87, no. 1, pp. 111-121, 2003, doi: https://doi.org/10.1016/j.rse.2003.07.002.

[50] L. Wang and J. J. Qu, "NMDI: A normalized multi-band drought index for monitoring soil and vegetation moisture with satellite remote sensing," Geophysical Research Letters, vol. 34, no. 20, pp. 1-5, 2007, doi: 10.1029/2007GL031021.

[51] N. Zhang, Y. Hong, Q. Qin and L. Liu, "VSDI: a visible and shortwave infrared drought index for monitoring soil and vegetation moisture based on optical remote sensing," International Journal of Remote Sensing, vol. 34, no. 13, pp. 4585-4609, Jul. 2013, doi: 10.1080/01431161.2013.779046.

[52] W. Fang et al., "Probabilistic assessment of remote sensing-based terrestrial vegetation vulnerability to drought stress of the Loess Plateau in China," Remote Sensing of Environment, vol. 232, no. July, p. 111290, 2019, doi: 10.1016/j.rse.2019.111290.

[53] A. F. S. Ribeiro, A. Russo, C. M. Gouveia and P. Páscoa, "Copula-based agricultural drought risk of rainfed cropping systems," Agricultural Water Management, vol. 223, p. 105689, 2019, doi: 10.1016/j.agwat.2019.105689.

[54] S. Nabaei, A. Sharafati, Z. M. Yaseen and S. Shahid, "Copula based assessment of meteorological drought characteristics: Regional investigation of Iran," Agricultural and Forest Meteorology, vol. 276-277, p. 107611, 2019, doi: 10.1016/j.agrformet.2019.06.010.

[55] D. Zuo et al., "Assessment of meteorological and agricultural droughts using in-situ observations and remote sensing data," Agricultural Water Management, vol. 222, no. May, pp. 125-138, 2019, doi: 
10.1016/j.agwat.2019.05.046.

[56] X. Liu, X. Zhu, Q. Zhang, T. Yang, Y. Pan and P. Sun, "A remote sensing and artificial neural network-based integrated agricultural drought index: Index development and applications," CATENA, vol. 186, p. 104394, 2020, doi: 10.1016/j.catena.2019.104394.

[57] H. Han, J. Bai, J. Yan, H. Yang and G. Ma, "A combined drought monitoring index based on multi-sensor remote sensing data and machine learning," Geocarto International, vol. 36, no. 10, pp. 1161-1177, Jun. 2021, doi: 10.1080/10106049.2019.1633423.

[58] J. Rhee and J. Im, "Meteorological drought forecasting for ungauged areas based on machine learning: Using longrange climate forecast and remote sensing data," Agricultural and Forest Meteorology, vol. 237-238, pp. 105-122, 2017, doi: 10.1016/j.agrformet.2017.02.011.

[59] N. Sazib, I. Mladenova and J. Bolten, "Leveraging the Google Earth Engine for Drought Assessment Using Global Soil Moisture Data," Remote Sensing, vol. 10, no. 8. 2018. doi: 10.3390/rs10081265.

[60] R. Shen, A. Huang, B. Li and J. Guo, "Construction of a drought monitoring model using deep learning based on multi-source remote sensing data," International Journal of Applied Earth Observation and Geoinformation, vol. 79, pp. 48-57, 2019, doi: 10.1016/j.jag.2019.03.006.

[61] T. L. Du, D. D. Bui, M. D. Nguyen and H. Lee, "Satellite-Based, Multi-Indices for Evaluation of Agricultural Droughts in a Highly Dynamic Tropical Catchment, Central Vietnam," Water, vol. 10, no. 5. 2018. doi: 10.3390/w10050659.

[62] M. Venkatappa, N. Sasaki, P. Han and I. Abe, "Impacts of droughts and floods on croplands and crop production in Southeast Asia - An application of Google Earth Engine," Science of The Total Environment, vol. 795, p. 148829, 2021, doi: 10.1016/j.scitotenv.2021.148829.

[63] O. Roswintiarti, P. Sofan and N. Anggraini, "Monitoring of Drought-Vulnerable Area in Java Island , Indonesia Using Satellite Remote-Sensing Data," Jurnal Pengeinderaan Jauh, vol. 8, no. Vci, pp. 21-34, 2011

[64] L. F. Amalo, R. Hidayat and S. Sulma, "Analysis of agricultural drought in east java using vegetation health index," Agrivita, vol. 40, no. 1, pp. 63-73, 2018, doi: 10.17503/agrivita.v40i1.1080.

[65] S. Y. J. Prasetyo, K. D. Hartomo, M. C. Paseleng, D. W. Chandra and E. Winarko, "Satellite imagery and machine learning for aridity disaster classification using vegetation indices," Bulletin of Electrical Engineering and Informatics, vol. 9, no. 3, pp. 1149-1158, 2020, doi: 10.11591/eei.v9i3.1916.

[66] R. I. Sholihah et al., "Identification of Agricultural Drought Extent Based on Vegetation Health Indices of Landsat Data: Case of Subang and Karawang, Indonesia," Procedia Environmental Sciences, vol. 33, pp. 14-20, 2016, doi: 10.1016/j.proenv.2016.03.051.

[67] F. Rismayatika, R. Saraswati, I. P. A. Shidiq and Taqyyudin, "Identification of Dry Areas on Agricultural Land using Normalized Difference Drought Index in Magetan Regency," IOP Conference Series: Earth and Environmental Science, vol. 540, no. 1, 2020, doi: 10.1088/1755-1315/540/1/012029.

[68] Y. Pramudya and T. Onishi, "Assessment of the Standardized Precipitation Index (SPI) in Tegal City, Central Java, Indonesia," IOP Conference Series: Earth and Environmental Science, vol. 129, no. 1, 2018, doi: 10.1088/17551315/129/1/012019.

\section{BIOGRAPHIES OF AUTHORS}

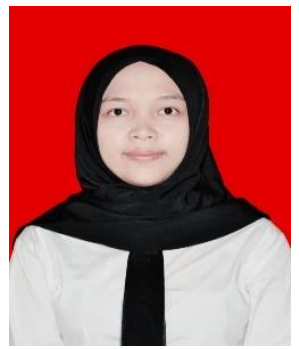

Khalifah Insan Nur Rahmi is currently a graduate student of Magister of Geography, Faculty of Mathematics and Science, Universitas Indonesia. She is also a researcher at Remote Sensing Application Centre LAPAN. She obtained a Bachelor of Science from the Faculty of Geography, Universitas Gadjah Mada. Ministry of Finance LPDP Scholarship supports her master's degree. Her research interest on remote sensing, environmental, and disaster management.

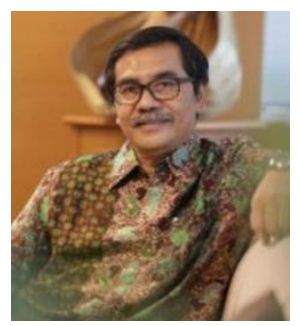

Muhammad Dimyati, was born in Solo. He obtained his BSc (1982) from the Faculty of Geography, Department of Remote Sensing, Gadjah Mada University, and Master (1990) and Doctoral Degree (1997) of Agricultural Science, Lab of Regional Planning, Tropical Agriculture Division, Faculty of Agriculture, Kyoto University, Japan. Since 1983-2005, he has been working for the Ministry of Public Works in Remote Sensing, Geographic Information Systems, and Spatial Planning. He was the Deputy Assistant of Large-Scale Area Development, then Deputy Assistant of Integrated Infrastructure, Deputy Assistant of Cooperation and Partnerships, and Deputy Assistant of Formal Housing Planning of the Ministry of Housings (2005-2014). He was the Deputy of Resources for Science and Technology of the Ministry of Science and Technology (2014-2015). He was a Director General of Strengthening for Research and Development, Ministry of Research, Technology, and Higher Education (2015-2020). Currently, he is an Associate Professor in the Department of Geography, Faculty of Mathematics and Natural Sciences, Universitas Indonesia. 